\title{
Influence of Leadership Against Employee Performance and Work Motivation To Improve the Quality of Public Services At PDAM Banjarmasin City
}

\author{
1. Dewi Merdayanty, (Coresponding author e mail\{dewiuntag@gmail.com ) \\ Student of Doctor Study Program of Administration Science- FISIP. \\ University 17 Agustus 1945 Surabaya, Semolowaru Street No 45 \\ Surabaya city - Indonesia \\ 2. V. Rudy Handoko ( e mail : rudyhandoko62@yahoo.com ) \\ 3. H. Achmad Sjafii ( e mail : achmadsyafii @Untag-sby.ac.id )
}

\begin{abstract}
The purpose of this study was to determine the effect of leadership on employee performance, the influence of leadership on work motivation, the influence of employee performance on public service quality and work motivation on the quality of public services. This research hopes to be able to provide input for the leadership of Bandarmasih PDAM in Banjarmasin City as a consideration in making a decision or policy for the organization. The research method using quantitative methods and types of research is descriptive research. Sampling through Slovin formula as many as 78 respondents used as primary data sources through questionnaires. The data analysis tool uses version 2 SmartPartial Last Square (SmartPLS v.2). The results showed that leadership gave a significant influence on employee performance with a positive relationship direction, leadership had a significant influence on work motivation with a positive direction. Employee performance does not have a significant effect on the quality of public services with the direction of negative relations and work motivation to have a significant influence on the quality of public services with the direction of positive relationships.
\end{abstract}

Keywords: Leadership, Performance, Motivation, Public Service

DOI: $10.7176 /$ PPAR/9-11-07

Publication date: November $30^{\text {th }} 2019$

\section{INTRODUCTIONS}

The establishment of an organization certainly has a goal in order to be in touch with social life, to be a useful organization for both the surrounding community and the wider community. Water Supply Management (PDAM) Bandarmasih Banjarmasin City is one of the organizations that provide drinking water to the people in Banjarmasin city, although Banjarmasin City is known as a city of a thousand rivers with abundant natural assets but the development of the era gives people awareness of the importance of using water clean and healthy in fulfilling everyday life. For this reason, Bandarmasih City PDAM in Banjarmasin is highly required to continue to progress and develop in order to provide maximum service for the people of Banjarmasin City, efforts to realize this need reliable management from the leadership of the Bandarmasih PDAM in Banjarmasin City. Leadership as a process of social influence, namely a life that influences the behavior of others towards achieving certain goals. The leadership approach taken by the leadership is closely related to the condition of an organization, because according to Soekarno (2015: 9) leadership will play a role and its dominant contribution in the life of the organization which always interacts with the environment which constantly changes, both in the internal environment, external environment and the global environment. Leadership must be able to influence and lead to compliance of its subordinates, besides leadership is also a role model for subordinates in achieving organizational goals. Therefore in leadership must have authority, ability and power in order to develop obedience to subordinates so that they can affect the performance of subordinates in order to realize public accountability to be able to provide maximum public services. The leadership approach in influencing employee performance can be done through a transformational leadership approach and transactional leadership, while the level of measurement for employee performance is done through responsiveness assessment, responsibility, accountability.

Leadership in principle is able to motivate subordinates to do better than what is usually done, in other words can increase the trust or confidence of subordinates so as to be able to encourage improvement in subordinate work, related to the work concept. activities (Nawawi, 2003: 328). Bawahan is also encouraged to improve and realize the improvement of the quality of public services, where this motivation can be done through motivational factors and hygiene factors. PDAM Bandarmasih City of Banjarmasin as an organization engaged in providing public services needs to build trust from the community for the implementation of public services that are in line with expectations and the demands of the community. Improvement of service is one of the elements that becomes a benchmark in maintaining the sustainability of the organization, therefore measuring 
the quality of public services in an organization is needed to determine the maximum level of the organization in an effort to provide services and meet expectations to the community. Measurement of the quality of public services can be measured through reability, responsiveness, assurance, empathy, tangibels.

Early observations of researchers at Banjarmasin Banjarmasin Band PDAM found news from BanjarmasinPost mass media on March 14, 2017 entitled Smoothly But Dirty, The Most Answer Questioner on the Service of Bandarmasih PDAM, where the Borneo Law Firm advocacy team released their questionnaire results, as follows: questionnaire then we conclude while that so far the service of PDAM Bandarmasih is still far from the maximum word. There was even one of the statements from the correspondent who sent a photo of the condition of the water in his house, which looked black, dirty and smelly. From the other side, precisely on the profile of Banjarmasin Bandarmasih City, the researchers found that "Bandarmasih PDAM continues to grow and innovate so that now the efforts of PDAM Bandarmasih have been named as one of the best water supply companies in the field of services in Southeast Asia". Moving on from this gap, the formulation of the problems in this study are as follows (1) Does leadership significantly influence the performance of employees at the Bandarmasih Regional Water Supply Company in Banjarmasin City. (2) Does leadership significantly influence motivation in Bandarmasih Regional Water Supply Company in Banjarmasin City. (3) Does the employee's performance have a significant effect on the quality of public services at the Bandarmasih Regional Water Company in Banjarmasin City. (4) Does motivation have a significant effect on the quality of public services at the Bandarmasih Regional Water Supply Company in Banjarmasin City.

\section{THINGKING CONCEPT}

\section{Leadership}

Leadership is someone who is able to influence other people to do or not do something that is desired (Sedarmayanti, 2009: 119). In this study the leadership theory used is the transformational leadership approach and transactional leadership. Transformational leadership is a process where people engage with others, and create relationships that increase motivation and morality in leaders and followers, and try to help followers reach their best potential. Pure transformational leadership is social leadership and caring for the common good, this social nature defeats their own interests for the good of others (Howell \&Avolio in Peter, 2013: 177).

Transformational leadership factors (Bass in Robbins, 2014: 188), that is:

\section{Ideal Influence}

Ideal influence describes a leader who acts as a strong role model for followers, while followers connect with the leader and really want to imitate them. These leaders usually have high standards of morals and ethical behavior, and can be relied upon to do the right thing, they are highly valued by followers who usually strongly believe in them, they give followers of mission and understanding mission. There are two components in this factor, namely the component of recognition that refers to the recognition of followers to leaders based on the perceptions they have of their leaders, and a component of behavior that refers to observations of followers of leader behavior.

2. Inspiring Motivation

This factor describes leaders who communicate high expectations to their followers, inspire them through the motivation to be loyal and become part of a shared vision in the organization.

3. Intellectual Stimulation

This includes leadership that stimulates followers to be creative and innovative and stimulate their own beliefs and values, as well as the values of the beliefs of leaders and organizations.

4. Individual Consideration

Leaders who provide a supportive climate, where they listen carefully to the needs of each follower, the leader acts as a coach and advisor while trying to help followers truly realize what they want. This leader uses delegates to help followers grow through personal challenges.

Burns in Peter (2013: 176) states that transactional leadership refers to a collection of useful leadership models on exchanges that occur between leaders and followers.

Factors that influence traditional leadership, (Bass in Robbins, 2014: 188):

1. Conditional Rewards

The process of exchange between leaders and followers, where followers' efforts are exchanged for certain rewards. Leaders try to get agreement from followers about what to do, and what rewards will be there for the people who do it. 


\section{Management and Exceptions}

Leadership that involves constructive criticism, negative feedback and negative encouragement, the leader uses management without exception in the passive form, carefully monitors the followers in case the followers make mistakes or violate regulations and then take corrective actions.

Performance

Performance is a measure and assessment of actual behavior in the workplace, the dimensions of performance include (Miner in Surya and Hananto, 2004: 35):

1. Quality of Output, Performance is stated to be good if the quality of the output produced is better or at least the same as the predetermined target.

2. Quantity of Output, performance is also measured by the amount of output produced. An individual is declared to have a good performance if the amount / quantity achieved can exceed or at least equal to the target that has been determined without ignoring the quality of the output.

3. Time at Work, time dimension is also a consideration in measuring one's performance. By not ignoring the quality and quality of output that must be achieved, an individual is considered to have good performance if the individual can complete the work in a timely manner.

4. Cooperation With Others' Work, performance is also assessed from the ability of an individual to remain cooperative with other workers, for example the ability to cooperate, the level of activity and the desire to progress.

The theory of employee performance is taken from the Lenvine literature in Dwiyanto (1999: 45), proposing three concepts to measure the performance of public organizations / non-business organizations:

1. Responsiveness

That is the ability of the organization to recognize community needs, set the agenda and priority of services and develop public service programs according to the needs and aspirations of the community. The more needs and desires of the people programmed and carried out by public organizations, the better the performance of public organizations.

2. Responsibility

Responsibility explains whether the implementation of public organization activities is carried out in accordance with administrative principles that are correct or in accordance with organizational policies. The more public organization activities are carried out in accordance with administrative principles, rules and organizational policies, the better the performance.

3. Accountability

Accountability refers to how many organizational policies and activities are subject to political officials elected by the people (elected officials). In this context the performance of public organizations is considered good if most of its activities are based on efforts to meet the expectations and desires of the people's representatives.

Motivation

Robbins and Judge (2008: 222) states that motivation is a process that explains the intensity, direction and provisions of an individual to achieve his goals.

Herzberg's theory in Hasibuan (2008: 229) states that there are two groups or factors in motivation theory according to the theory proposed by Herzberg which are classified as motivational factors and hygienic factors.

Herzberg developed a model of two factors of motivation, (Siagian, 2011: 164):

1. Motivasional Factors

Things that encourage achievement that are intrinsic in nature, meaning derived from within a person.

2. Hygiene Factors

Known as maintenance are extrinsic factors which mean that they originate from outside themselves that also determine a person's behavior.

Quality of Public Service

Service quality according to Kotler (2005: 153) is a model that describes the condition of customers in forming expectations of services from past experience, promotion from quality to mouth, and advertising by comparing the services they expect with what they receive / feel. While public services are also referred to as services to the public (community) or public services. The Law of the Republic of Indonesia No. 25 of 2009 states that public services are activities in the context of fulfilling service needs in accordance with the laws and 
regulations for every citizen and resident for administrative goods, services and / or services provided by public service providers..

According to Zeithaml in Hussein (2005: 153), there are five dimensions to determine service quality, as follows:

1. Reability, namely the ability to provide services that are in accordance with the promises offered.

2. Responsiveness, is the response or alertness of employees in helping customers and providing fast and responsive service, which includes: employee readiness in handling transactions, and handling customer complaints.

3. Assurance, this aspect includes the ability of employees to: knowledge of the product appropriately, quality of hospitality, attention and politeness in providing services, skills in providing information, ability to provide security in utilizing the services offered, and the ability to instill customer trust in the company.

4. Emphaty, is the individual attention given by the company to customers such as the ease of contacting the company, the ability of employees to communicate with customers, and the company's efforts to understand the wants and needs of its customers.

5. Tangibles, this dimension includes the appearance of physical facilities such as buildings and front office rooms, the availability of parking spaces, cleanliness, neatness, and comfort of the room, the completeness of communication equipment and appearance of employees.

\section{MATERIAL AND METHODS}

This research method uses quantitative methods, according to Sugiyono (2011: 14) quantitative method is a research method as a method based on the philosophy of positivism, a method used to examine certain populations or samples, sampling techniques are usually carried out by calculating certain appropriate sample techniques , quantitative / statistical data collection with the aim of testing predetermined hypotheses. This type of research uses descriptive research, which describes existing phenomena, which take place at this time or in the past. According to Bungin (2014: 44) quantitative research with descriptive format aims to explain, summarize various conditions, various situations, or various variables that arise in the community that are the object of research based on what happened. Then raise to the surface of the character or description of the condition, situation, or variable. The conclusion of this study involved all employees of Bandarmasih PDAM in Banjarmasin City, amounting to 362 employees, and for sampling this study using Slovin formula, with a percentage of $10 \%$ allowance, as follows :

$$
\begin{aligned}
& \mathrm{n}=\frac{\mathrm{N}}{1+\mathrm{Ne}^{2}} \\
& \mathrm{n}=\frac{362}{1+362(0.1)^{2}}=78,35 \text { adjusted to } 78 \text { respondents }
\end{aligned}
$$

Data collection techniques through primary data and secondary data, where the primary data comes from the distribution of questionnaires to respondents, while secondary data sourced from the archive and documentation at PDAM Bandarmasih Banjarmasin City. Data that has been successfully collected was analyzed using Smart Partial Least Square (SmartPLS) analysis tools.

Research Hypothesis

1. $\mathrm{H}_{0}=$ Leadership does not have a significant effect on employee performance at the Bandarmasih Regional Water Company in Banjarmasin City.

$\mathrm{H}_{1}=$ Leadership has a significant effect on employee performance at the Bandarmasih Regional Water Company in Banjarmasin City.

2. $\mathrm{H}_{0}=$ Leadership does not have a significant effect on motivation in the Bandarmasih Regional Water Company in Banjarmasin City.

$\mathrm{H}_{1}=$ Leadership has a significant effect on motivation in the Bandarmasih Regional Water Company in Banjarmasin City.

3. $\mathrm{H}_{0}=$ Employee performance has no significant effect on the quality of service at the Bandarmasih Regional Water Company in Banjarmasin City. 
$\mathrm{H}_{1}=$ Employee performance has a significant effect on the quality of service at the Bandarmasih Regional Water Supply Company in Banjarmasin City.

4. $\mathrm{H}_{0}=$ Motivation does not have a significant effect on the quality of service at the Bandarmasih Regional Water Company in Banjarmasin City.

$\mathrm{H}_{1}=$ Motivation has a significant effect on the quality of service at the Bandarmasih Regional Water Supply Company in Banjarmasin City.

\section{RESULT AND DISCUSSION}

Testing data validity and reliability

Every data that has been obtained from the respondent, before it is processed to test the hypothesis, then firstly test the validity and reliability of the data. The following is the output of the measurement model or outer model with SmartPLS, as follows:

Image 1 Full Outer Model

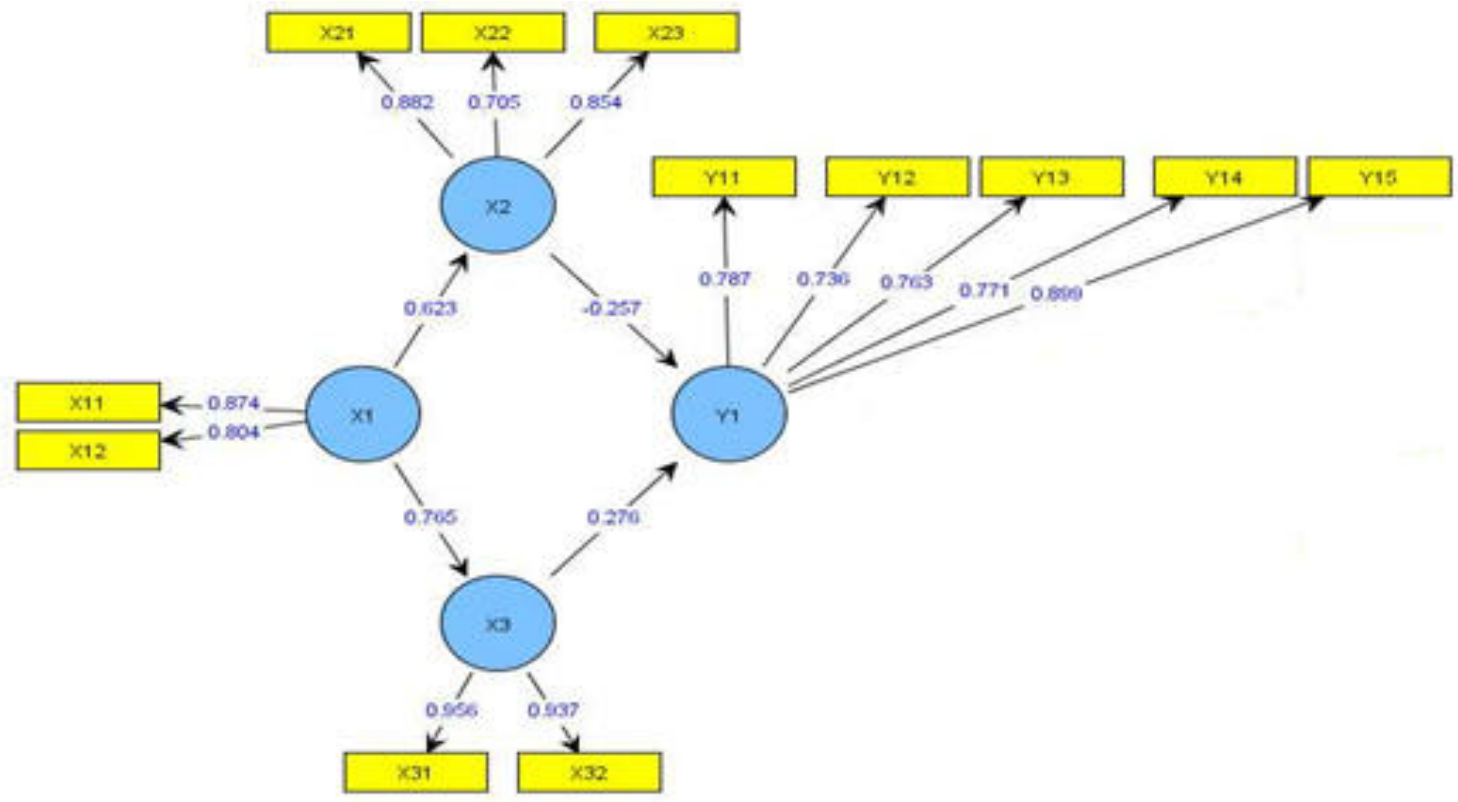

Information:

$\mathrm{X}_{1}$ is a leadership variable and the indicators are (X1.1) transfomational leadership and (X1.2) transactional leadership.

$\mathrm{X}_{2}$ is variable employee performance and the indicator is (X2.1) Responsiveness, (X2.2) Responsibility and accountability (X2.3)

$\mathrm{X}_{3}$ is a variable of work motivation and the indicators are motivational (X3.1) and Hygiene (X3.2)

$\mathrm{Y}_{1}$ is the variable quality of public service and the indicator is tangible (Y1.1), reability (Y1.2), responsiveness (Y1.3), assurance (Y1.4) and emphaty (Y1.5). 
The following is the OuterSmartPLS Report, for Outer Loading

Table1 Outer Model (Outer Loading)

\begin{tabular}{|c|c|c|c|c|}
\hline & $\left(\mathrm{X}_{3}\right)$ & $\left(\mathrm{X}_{2}\right)$ & $\left(\mathrm{X}_{1}\right)$ & $\left(\mathrm{Y}_{1}\right)$ \\
\hline $\mathrm{X} 11$ & & & 0,874 & \\
\hline $\mathrm{X} 12$ & & 0,882 & & \\
\hline $\mathrm{X} 21$ & & 0,705 & & \\
\hline $\mathrm{X} 22$ & & 0,854 & & \\
\hline $\mathrm{X} 23$ & & & & \\
\hline $\mathrm{X} 31$ & 0,956 & & & 0,784 \\
\hline $\mathrm{X} 32$ & 0,937 & & & 0,737 \\
\hline $\mathrm{Y} 11$ & & & & 0,761 \\
\hline $\mathrm{Y} 12$ & & & & 0,899 \\
\hline $\mathrm{Y} 13$ & & & & \\
\hline $\mathrm{Y} 14$ & & & & \\
\hline $\mathrm{Y} 15$ & & & & \\
\hline
\end{tabular}

Test the validity of the data is done by using convergent validity of the amount of loading factor for each $>0.50$ towards the intended variable. In the table above shows that all loading factors show $>0.50$ so that all indicators are declared valid and can be continued in the next test.

Table2 Measurement with Composite Reliability

\begin{tabular}{|c|c|}
\hline Variabel & Composite Reliability \\
\hline $\mathrm{X}_{1}$ & 0,827 \\
\hline $\mathrm{X}_{2}$ & 0,857 \\
\hline $\mathrm{X}_{3}$ & 0,946 \\
\hline $\mathrm{Y}_{1}$ & 0,894 \\
\hline
\end{tabular}

Next to determine composite reliability, if the composite reliability value is $>0.8$ it can be said that the construct has high reliability. The reliability test results with composite reliability in the table above stated reliable and feasible to be used to determine the effect of dependent latent variables.

Table3 R Square

\begin{tabular}{|c|c|}
\hline & R Square \\
\hline X2 & 0,389 \\
\hline X3 & 0,586 \\
\hline Y1 & 0,031 \\
\hline
\end{tabular}


Viewed from the table above, the R Square results can be explained that the influence of Leadership variable (X1) on Employee Performance (X2) with a value of 0.389 which means that Leadership (X1) has an effect of $38.9 \%$ on Employee Performance (X2 ) while the remaining $61.1 \%$ is influenced by other variables. Then the Leadership variable (X1) on Motivation (X3) with a value of 0.586 which means that Leadership (X1) has an effect of $58.6 \%$ on Work Motivation (X3) while the remaining $41.4 \%$ is influenced by other variables. Then Employee Performance (X2) and Work Motivation (X3) on Public Services (Y1) with a value of 0.031 means Employee Performance (X2) and Work Motivation (X3) gives an influence of $3.1 \%$ on Public Services (Y1) while the remaining $96,9 \%$ is influenced by other variables.

\section{Hypothesis Testing}

The hypothesis testing criteria with a significance level $(\alpha)$ of $5 \%$ with the provision that $\mathrm{t}$-count $>\mathrm{t}$ table is more than 1.96, then the hypothesis is accepted, and if $\mathrm{t}$ count $<\mathrm{t}$ table, which is less than 1.96, the hypothesis is rejected. The bootstrapping PLS output to test the research hypothesis is as follows:

\section{Image2 Bootsatraping PLS}

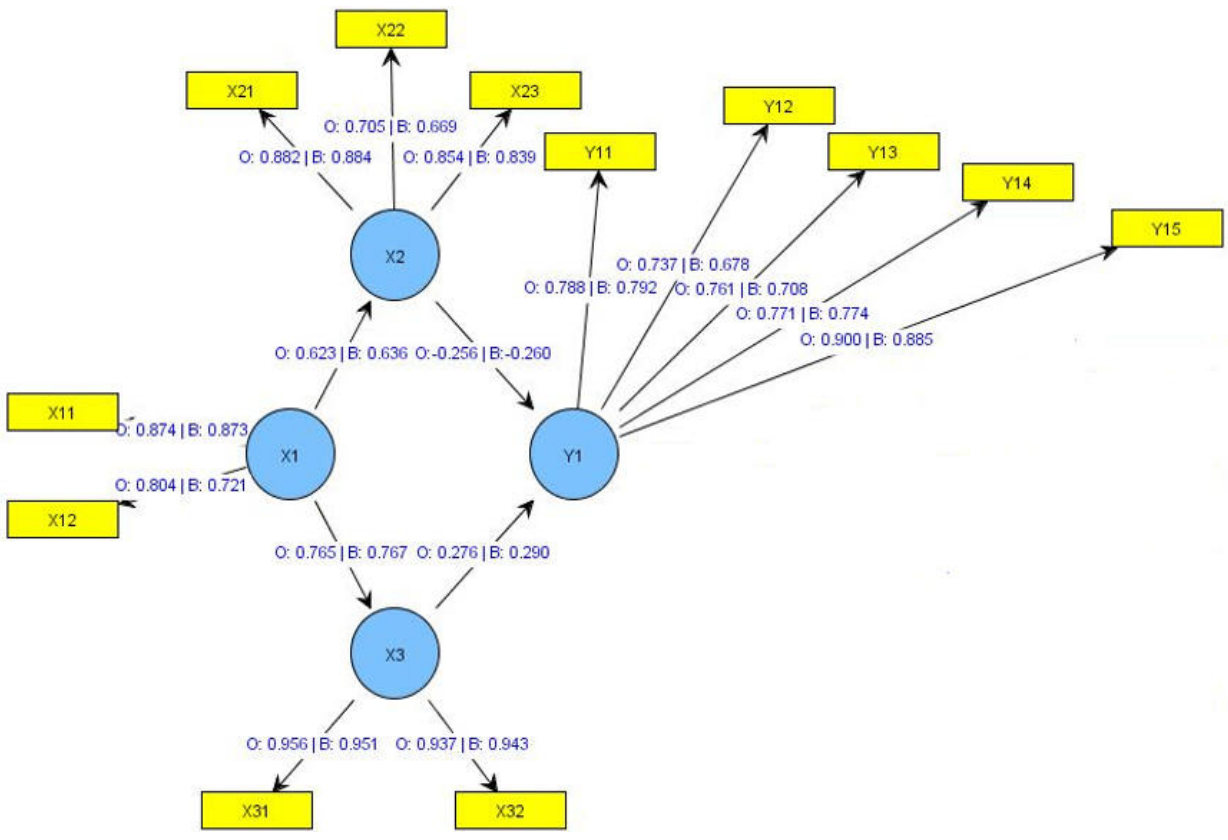

Table4 Hypothesis Testing 1 : Effect of Leadership on Employee Performance

\begin{tabular}{|c|c|c|c|c|}
\hline & $\begin{array}{c}\text { Original Sample } \\
(0)\end{array}$ & $\begin{array}{c}\text { Sample Mean } \\
(\mathrm{M})\end{array}$ & $\begin{array}{c}\text { StandarDeviasi } \\
(\mathrm{STDEV})\end{array}$ & $\begin{array}{c}\mathrm{t}-\text { statistic } \\
(|\mathrm{O} / \mathrm{STDEV}|)\end{array}$ \\
\hline $\mathrm{X} 1->\mathrm{X} 2$ & 0,623 & 0,636 & 0,149 & 4,194 \\
\hline
\end{tabular}

The 1st hypothesis which examines the relationship between Leadership to Employee Performance, shows the original sample value of 0.623 and $t$-statistics 4.194 . The measurement results show that $t$-statistic $>\mathrm{t}$-table, then $\mathrm{H} 1$ is accepted. From the results of the data, leadership can be interpreted to have a significant influence on employee performance, with a positive relationship direction. This gives meaning, if the perception of leadership on performance is applied to Bandarmasih PDAM, the better (positive), the higher the employee's performance. Conversely, if the perception of leadership on the performance applied to Bandarmasih PDAM is getting worse (negative), then the performance of employees will be lower.Leadership efforts at Bandarmasih PDAM in Banjarmasin in improving employee performance through the organization's vision that has been set to make 
PDAM Bandarmasih Sehat, Mandiri, and Prima in Services, and the mission of PDAM Bandarmasih, namely (1) PDAM Bandarmasih Full Cost Recovery, (2) service prime, quality, quantity, continuity and pressure, (3) professional and prosperous employees and (4) contributing to local revenue. The leadership of Bandarmasih PDAM also instills in employees the sense of pride in being a workforce capable of providing services to the community and instilling the principle of the importance of values and beliefs in doing work. The leadership of Bandarmasih PDAM in Banjarmasin City also gives encouragement to employees to develop in doing work by providing direction and expressing important organizational goals and the process of achieving organizational goals. the leader of Bandarmasih PDAM always promotes ideas to innovate, this has been proven since the initial operation of clean water distribution capacity of 35 liters / second is only intended for urban communities, and now the distribution capacity of clean water has reached 1000 liters / second which has penetrated regions urban suburbs. In its development, of course, every organization experiences a variety of obstacles, leadership actions towards problems within the organization are seen rationally from various perspectives and solve problems carefully through various perspectives and provide new ways to solve work constraints. Providing training to teach and foster in carrying out work and provide advice on developing employee capabilities. Leadership conducts agreements on things that need to be done by subordinates as job descriptions in carrying out their duties and promises rewards that will be obtained if the objectives in each of the agreed units of the organization have been achieved, either through giving incentives or awards to subordinates, leaders directly monitoring deviation from established work standards, followed by evaluation as the lead of the leader to always carry out corrective actions, the leader will take action if the standards set at one particular organizational unit are not achieved and maintain and develop quality standards for other organizational units who have achieved the goals of organizational goals with the principle of continuous innovation. At certain positions the leadership gives authority to subordinates so that subordinates can develop with their respective potential to achieve work performance in order to improve employee performance both team work and individuals, thus indirectly cadre as leader of the organization will also be able to develop.

Table5 Hypothesis Testing 2 : Effect of Leadership on Work Motivation

\begin{tabular}{|c|c|c|c|c|}
\hline & $\begin{array}{c}\text { Original Sample } \\
(0)\end{array}$ & $\begin{array}{c}\text { Sampel Mean } \\
(\mathrm{M})\end{array}$ & $\begin{array}{c}\text { StandarDeviasi } \\
(\text { STDEV })\end{array}$ & $\begin{array}{c}\mathrm{t} \text { - statistic } \\
(|\mathrm{O} / \mathrm{STDEV}|)\end{array}$ \\
\hline $\mathrm{X} 1->\mathrm{X} 3$ & 0,765 & 0,767 & 0,070 & 10,956 \\
\hline
\end{tabular}

The second hypothesis which examines the relationship between leadership and work motivation, shows the original sample value of 0.765 and t-statistics of 10.956 . The measurement results show that t-statistic $>$ t-table, then $\mathrm{H} 1$ is accepted. From the results of these data, leadership can be interpreted to have a significant influence on work motivation, with a direction of positive relationships. This gives meaning, if the perception of leadership towards work motivation is applied to Bandarmasih PDAM in Banjarmasin City, the better (positive), the higher the work motivation. Conversely, if the perception of leadership on work motivation is applied to Bandarmasih PDAM, Banjarmasin City is getting worse (negative), then work motivation will be lower.

Bandarmasih PDAM is very concerned about human resources (HR) in the company through efforts to create professional and prosperous employees with the aim that the creation of human resources who have technical / non-technical and managerial skills, is expected not only to be able to drive the company's wheels, but also encourage better corporate sustainability . Leaders encourage employee achievement that is intrinsic in nature, such as encouraging and encouraging employees to perform in carrying out their duties and giving appreciation / recognition for every achievement achieved by employees, PDAM Bandarmasih leadership also gives employees the freedom to be creative in doing work and emphasize employees to have responsibilities tall one. In addition, leadership communication with subordinates is always intertwined to provide enthusiasm to work for the progress and growth of the organization, the head of PDAM Bandarmasih also provides policies related to attention to security and security in working both in terms of financial stability in the organization and security in carrying out tasks. Whereas the leadership encourages extrinsic employee achievement, through establishing policies and administrative systems that are accommodating for employees, fostering a future career while working for the PDAM and providing policies related to the right position for employees in carrying out tasks followed by providing guidance and direction to subordinates so that they can creating a pleasant and conducive working atmosphere between superiors and subordinates as well as colleagues, as well as the incentive policies provided by the leadership of the PDAM Bandarmasih felt to be fair enough for the subordinates. 
Table 6 Hypotesis Testing 3 : Effect of Leadership on Work Motivation

\begin{tabular}{|c|c|c|c|c|}
\hline & $\begin{array}{c}\text { Original Sample } \\
(0)\end{array}$ & $\begin{array}{c}\text { Sampel Mean } \\
(\mathrm{M})\end{array}$ & $\begin{array}{c}\text { StandarDeviasi } \\
(\text { STDEV })\end{array}$ & $\begin{array}{c}\mathrm{t} \text { - statistic } \\
(|\mathrm{O} / \mathrm{STDEV}|)\end{array}$ \\
\hline $\mathrm{X} 2->\mathrm{Y} 1$ & $-0,256$ & $-0,260$ & 0,207 & 1,238 \\
\hline
\end{tabular}

The third hypothesis which examines the relationship between Employee Performance and Public Service, shows the original sample value of -0.256 and $t$-statistic of 1.238 . The measurement results show that the tstatistic $<\mathrm{t}$-table, then $\mathrm{H} 0$ is accepted and $\mathrm{H} 1$ is rejected. From the results of the data, it can be interpreted that employee performance does not have a significant effect on public services with a negative relationship direction. This means that if the performance of employees at PDAM Bandarmasih City of Banjarmasin is good or not good then it will not affect good or poor public services at PDAM Bandarmasih City of Banjarmasin. Based on these findings, it will be a consideration for leaders in making a decision or policy, where consideration is not only seen from one perception but must combine perceptions of employee performance and perceptions of the quality of public services, so that conditions and levels of organizational development can known by the leadership comprehensively, because the progress and withdrawal of an organization is the responsibility of the leadership.

Bandarmasih PDAM of Banjarmasin City has endeavored in developing the organization through employee performance perspectives so that employees are able to recognize the needs of the community, able to arrange public service agenda and priorities and develop public service programs in accordance with the needs and expectations of the community, employees are also expected to be able to carry out tasks in accordance administration principles, regulations and organizational policies, so that employee performance can provide information on expectations, suggestions, direction and views, both from the public and from those who represent the community. The information that has been explored will be the data for the leadership to be taken into consideration by the leadership in making decisions. Bandarmasih PDAM Banjarmasin City has also sought to support developing organizations through a public service perspective, in addition to clean water output for the community, PDAM also provides easy use of modern devices operationalized to speed up and simplify services. Placement of officers in accordance with their expertise and skills and always ready during predetermined working hours. Officers are ready to provide information and respond to user complaints and ease of communication with users.

Tabel 7Hypothesis Testing 4 : Effect of Leadership on Work Motivation

\begin{tabular}{|c|c|c|c|c|}
\hline & $\begin{array}{c}\text { Original Sample } \\
(0)\end{array}$ & $\begin{array}{c}\text { Sampel Mean } \\
(\mathrm{M})\end{array}$ & $\begin{array}{c}\text { StandarDeviasi } \\
(\text { STDEV })\end{array}$ & $\begin{array}{c}\mathrm{t} \text { - statistic } \\
(|\mathrm{O} / \mathrm{STDEV}|)\end{array}$ \\
\hline $\mathrm{X} 3$-> Y1 & 0,276 & 0,290 & 0,188 & 1,463 \\
\hline
\end{tabular}

The 4th hypothesis which examines the relationship between motivation to public services, shows the original sample value of 0.276 and t-statistics 1.463 . The measurement results show that t-statistic $>\mathrm{t}$-table, then $\mathrm{H} 1$ is accepted. From the results of the data, work motivation can be interpreted to have a significant effect on public services, with a positive relationship direction. This gives meaning, if the perception of work motivation on public services is applied to Bandarmasih PDAM in Banjarmasin City is getting better (positive), then work motivation will be higher. Conversely, if the perception of work motivation towards public services is applied to Bandarmasih PDAM, Banjarmasin City is getting worse (negative), then public services are getting lower.

Bandarmasih PDAM continues to develop and innovate so that now the efforts of PDAM Bandarmasih have been named as one of the best water supply companies in the field of service in Southeast Asia, even though it does not make Bandarmasih PDAM fast complacent, but even more achievement is driving it to further improve services to the community, especially the city of Banjarmasin, especially to achieve one hundred percent service coverage. The one hundred percent service coverage target is considered realistic as well as strategic because currently the service of PDAM Bandarmasih has reached $98.53 \%$ of the Banjarmasin City area. With this background Bandarmasih PDAM formulated its vision "to make PDAM Bandarmasih Sehat, Mandiri, and Prima in Services", it is expected that PDAM will become the best, independent and professional drinking water company in service. The next innovation based on the vision of PDAM Bandarmasih can be described as follows, (1) the first step in becoming the best water supply company in Asia is to become one of the best service 
PDAMs in Southeast Asia, (2) Hope to become a water provider net Asian level can be achieved by carrying out various efforts as outlined in the mission. Clarity of the vision and mission of the Bandarmasih PDAM will be a supporting component for employee motivation to work hand in hand to realize together the vision and mission that has been set. In addition, the vision will also provide direction for the company's development in the future to provide high public services. Public service efforts implemented by Bandarmasih PDAM in the form of modern devices to accelerate or simplify services, facilities prepared are easy to operate and always strive for good quality piped water, in 2014 Bandarmasih PDAM has achieved almost one hundred percent coverage for all Banjarmasin communities and surrounding, so that people do not encounter problems in getting clean water, supporting infrastructure that meets the standards and needs of consumers where the Bandarmasih PDAM Service in Banjarmasin City covers four plus service zones for Banjarmasin city people, namely for zone I for West Banjarmasin Subdistrict, zone II for East Banjarmasin Subdistrict, zone III for South Banjarmasin District and zone IV for North Banjarmasin District. And for the piped water treatment plant itself, in addition to the main center located in Bandarmasih PDAM itself, it is assisted by four intakes of water treatment plants, namely Intake located in Sungai Bilu Village, Pematang Panjang Village, Banua Anyar Village and in Sungai Lulut Village, all of these Intakes are in the East Banjarmasin sub-district. The reliability of officers in performing services in accordance with their expertise and skills in their respective fields, and the presence of officers are always ready at each working hour so that the community as service users immediately get repair services in the event of damage or error, officers conveying information is always administered to quickly, precisely and can be accounted for. The response of officers in providing services always prioritizes politeness, friendliness and respect in the implementation and completion of services, every complaint and complaint from service users is always followed in detail and answered immediately. Bandarmasih PDAM also provides online media programs as a fast and appropriate tool for feedback from user complaints. Through knowledge, insights and abilities of officers can lead to confidence and guarantee of security for users. Guarantees provided to users in accordance with the specified service time, fees paid by users of piped water services and repairs in accordance with the output or services obtained. Emphati's attitude was realized by officers by giving full attention and sincerity to service users, among giving special attention to users who experience problems, as well as providing convenience in communicating with users..

\section{CONCLUSION}

1. The Influence of Leadership on Employee Performance at the Bandarmasih Regional Water Company in Banjarmasin City.The results of hypothesis testing show that leadership has a significant influence on employee performance, with a positive relationship direction. This gives meaning, if the perception of leadership on performance is applied to Bandarmasih PDAM, the better (positive), the higher the employee's performance. Conversely, if the perception of leadership on employee performance is applied to Bandarmasih PDAM is getting worse (negative), then the performance of employees is lower. The efforts made by the leadership of Bandarmasih PDAM in improving employee performance are through the application of the organization's vision and mission, instilling a sense of pride in being able to provide services to the community, giving encouragement and direction to the organization's important goals and achievement processes through ideas to innovate, leadership actions towards problems faced rationally and solve problems carefully and provide solutions. Leadership also provides training and coaching from job description agreements that have been set by the organization and rewards the achievement of organizational goals in each unit, leadership continues to carry out corrective actions if there are targets of organizational unit work that have not been achieved. At a certain position the leadership gives delegation of authority to subordinates in order to develop with their potential, in team work as well as individuals, thus the cadre as leader of the organization will be built.

2. Effect of Employee Performance on the Quality of Public Services at the Regional Water Supply Company Bandarmasih Banjarmasin City.

The results of hypothesis testing show that employee performance does not have a significant effect on public services with a negative relationship direction. This gives the meaning that if the performance of employees at PDAM Bandarmasih City of Banjarmasin is good or not good, it will not affect the good or less good public service at PDAM Bandarmasih, Banjarmasin City. This finding is a consideration for leaders in making a decision, to consider and combine perceptions of employee performance and perceptions of the quality of public services comprehensively, because the progress and withdrawal of an organization is the responsibility of the leadership. Some of the efforts of PDAM Bandarmasih Kota Banjarmasin to develop the organization through the perspective of employee performance so that employees are able to recognize the needs of the community, are able to set the agenda and priority of public services and develop public service 
programs in accordance with the needs and expectations of the community, and are able to carry out tasks in accordance with administrative principles, organizational rules and policies, so that employee performance can provide information on expectations, suggestions, direction from the community and from those who represent the community. Whereas through the public service perspective, besides the output of clean water for the community, the PDAM also provides the use of modern devices that are easy to operate to speed up and facilitate services. Placement of officers who are in accordance with their expertise and skills and are always ready during predetermined working hours. Officers are ready to provide information and respond to user complaints and ease of communication with users

3. The Effect of Work Motivation on the Quality of Public Service at the Bandarmasih Regional Water Company in Banjarmasin City.

Work motivation has a significant influence on public services, with a positive relationship direction. This gives meaning, if the perception of work motivation towards public services is applied to Bandarmasih PDAM in Banjarmasin City, the better (positive), the higher the work motivation. Conversely, if the perception of work motivation towards public services is applied to Bandarmasih PDAM, Banjarmasin City is getting worse (negative), then public services are getting lower.

Bandarmasih PDAM, Banjarmasin city continues to develop and innovate so that now the effort has been given the title as one of the best water supply companies in the field of services in Southeast Asia, and targets service coverage of one hundred percent, until the achievement target has reached $98.53 \%$ of Banjarmasin . From the vision of PDAM Bandarmasih "to make PDAM BandarmasihSehat, Mandiri, and Prima in Services", it is expected that PDAM will become the Independent, Professional and best Drinking Water Company in service. Innovation from the vision of Bandarmasih PDAM is to realize the company as the best provider of drinking water in the service sector in Asia. Clarity of the vision and mission of PDAM Bandarmasih will be a supporting component for employee motivation to work hand in hand to realize together the vision and mission that has been set, Implementation of public services implemented by Bandarmasih PDAM by organizing modern devices to accelerate or simplify operational services. In addition to striving for high quality tap water, supporting infrastructure was formed to meet consumer standards and needs. Determining service personnel in accordance with expertise and skills, with knowledge, insight and ability of officers can lead to confidence and guarantee of security for service users

\section{SUGGESTIONS}

The leadership role gives influence in shaping and supporting the development of an organization, through decision making which is implemented jointly. Assessment of an organization comes from within the organization and from outside the organization, so that the progress of the organization is not only judged by the high level of performance of employees originating from within the organization but also judged by the high level of public services from outside the organization. Assessments of public services are multidimensional in nature that can be assessed both from the organization's side but can be judged by parties outside the organization, in the PDAM Bandarmasih City Banjarmasin agency the assessment of public services from parties outside the organization is found in its users, namely Banjarmasin City community. Bandarmasih PDAM in Banjarmasin City still needs to improve its ability to recognize community needs, this is evidenced from the results of research that employee performance has no significant effect on public services. Bandarmasih PDAM needs to maximize service priorities and develop public service programs in accordance with the needs and aspirations of the community through the principles of administration that is fast, precise, efficient and effective by optimizing the use of resources that are owned by both human resources and other resources.

\section{REFERENCE}

Banjarmasin Post, March 14, 2017, PT. Grafika Wangi, Banjarmasin.

Bungin, Burhan, 2014, Quantitative research methodology for Communication, Economics, and Public Policy and Other Social Sciences, Kencana Prenada Media Group, Jakarta.

Dwiyanto, Agus 2006, Assessment of Public Service Organizational Performance, Yogyakarta: Faculty of Social Sciences UGM.

Hasibuan, Malayu S.P., 2010. Organization and Basic Motivation for Increasing Productivity, PT. Bumi Aksara, Jakarta.

Kotler, Philip. 2005, Marketing Management, PT. Gramedia Group Index, Jakarta.

Nawawi, Hadari. 2003, Effective Organizational Leadership, Bumi Aksara, Jakarta.

Northouse, Peter G, 2013, Leadership: Theory and Practice, Translator Dr. Ati Cayani, PT. Index, Jakarta.

Robbins, Stephen P \& Timothy A. Judge, 2008. Perilaku Organisasi, Salemba Empat, Jakarta.

Robbins, Stephen P. 2014, Essential of Organizational Behavior, terjemah Yusuf Udaya, Arcan, Jakarta. 
Sedarmayanti, 2009. Human Resources and Work Productivity, CV. Mandar Maju, Bandung.

Siagian, Sondang P., 2011. Motivation Theory and Its Application, Rineka Cipta, Jakarta.

Soekarno Iskandar, 2015, Theoretical and Practical Study Leadership, Erlangga,

Sugiyono, 2011, Administrative Research Methods completed with R \& D Method, Alfabeta, Bandung.

Surya, Reza and Santosa Tri Hananto, 2004, Effects of Emotional Quotient Auditors on Auditor Performance in Public Accounting Firms, Perspective, Volume, Number 1.

Umar, Hussein, 2005, Corporate Performance Evaluation, Gramedia Main Library, Jakarta.

Law of the Republic of Indonesia Number 25 of 2009 concerning Public Services.. 